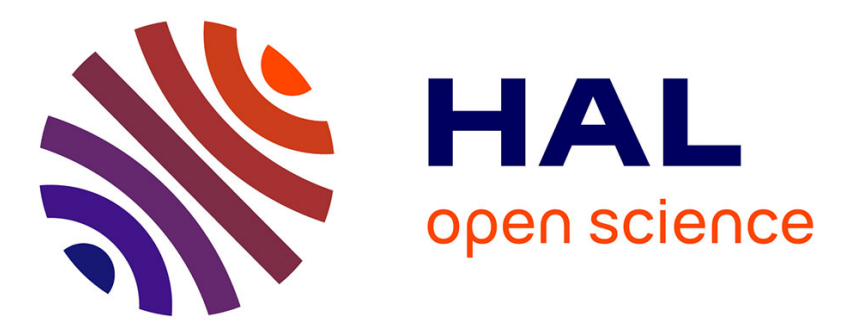

\title{
Temperature as a constraint on the timing and duration of African elephant foraging trips
}

\author{
David Rozen-Rechels, Hugo Valls-Fox, Cheryl Tinashe Mabika, Simon
}

Chamaillé-Jammes

\section{- To cite this version:}

David Rozen-Rechels, Hugo Valls-Fox, Cheryl Tinashe Mabika, Simon Chamaillé-Jammes. Temperature as a constraint on the timing and duration of African elephant foraging trips. Journal of Mammalogy, 2020, 10.1093/jmammal/gyaa129 . hal-03025138

\section{HAL Id: hal-03025138 \\ https://hal.science/hal-03025138}

Submitted on 26 Nov 2020

HAL is a multi-disciplinary open access archive for the deposit and dissemination of scientific research documents, whether they are published or not. The documents may come from teaching and research institutions in France or abroad, or from public or private research centers.
L'archive ouverte pluridisciplinaire HAL, est destinée au dépôt et à la diffusion de documents scientifiques de niveau recherche, publiés ou non, émanant des établissements d'enseignement et de recherche français ou étrangers, des laboratoires publics ou privés.

\section{(c)(1)}

Distributed under a Creative Commons Attribution| 4.0 International License 
Running header: Trip timing in African elephants

\section{Temperature as a constraint on the timing and duration of African elephant foraging trips}

David Rozen-Rechels, Hugo Valls-Fox, Cheryl Tinashe Mabika, And Simon ChamailléJAMMES

Sorbonne Université, CNRS, IRD, INRA, Institut d'écologie et des sciences de l'environnement (IEES), 4 Place Jussieu, 75252 Paris Cedex 5, France (DRR)

Max Planck Institute of Animal Behavior, Department of Collective Behavior, Universitätsstraße 10, Konstanz, 78457, Germany (Current address of DRR)

SELMET, Univ de Montpellier, CIRAD, INRA, Montpellier Sup. Agro, Montpellier, France (HVF)

Scientific Services, Zimbabwe Parks and Wildlife Management Authority, Hwange National Park, Zimbabwe (CTM)

CEFE, Univ de Montpellier, CNRS, EPHE, IRD, Unive Paul Valéry Montpellier 3, Montpellier, France (SCJ)

Mammal Research Institute, Department of Zoology and Entomology, Faculty of Natural and Agricultural Sciences, University of Pretoria, Hatfield, Pretoria, South Africa (SCJ)

*Correspondent: david.rozen-rechels@normalesup.org 
In arid and semi-arid environments, water is a key resource that is limited in availability. During the dry season, perennial water sources such as water pans often are far apart and shape the daily movement routines of large herbivores. In hot environments, endotherms face a lethal risk of overheating that can be buffered by evaporative cooling. Behavioral adjustments are an alternative way to reduce thermal constraints on the organism. The trade-off between foraging and reaching water pans has been studied widely in arid environments; however, few studies have looked into how ambient temperature shapes individual trips between two visits to water. In this study, we tracked during the dry season the movement of 8 GPS-collared African elephants (Loxodonta africana) cows from different herds in Hwange National Park, Zimbabwe. This species, the largest extant terrestrial animal, is particularly sensitive to heat due to its body size and the absence of sweat glands. We show that most foraging trips depart from water at nightfall, lowering the average temperature experienced during walking. This pattern is conserved across isolated elephant populations in African savannas. We also observed that higher temperatures at the beginning of the trip lead to shorter trips. We conclude that elephants adjust the timing of foraging trips to reduce the thermal constraints, arguing that further considerations of the thermal landscape of endotherms are important to understand their ecology.

Keywords: activity rhythm, large herbivore, movement ecology, nycthemeral, savanna, surface water

Water is a key resource for organisms living in dry environments (Davis and DeNardo 2009; Kemp and McKechnie 2019; McKinley et al. 2018; Mitchell et al. 2018). Endotherms produce their own heat at high energy and water costs. They have evolved diverse strategies to thermoregulate and minimize water loss. Birds and mammals living in arid and semi-arid environments, possess diverse physiological adaptations to regulate water loss, such as evaporative cooling (sweating, panting, 
passive cutaneous or respiratory water losses; Cain III et al. 2006; Gerson et al. 2014; Tieleman and Williams 2002), changing skin permeability to limit cutaneous water losses (Muñoz-Garcia et al. 2016; O'Connor et al. 2017), or even heterothermy (facultative hyperthermia by allowing body temperature to rise temporarily, Hetem et al. 2010, 2016; Gerson et al. 2019). Behavioral adjustments also are used to reduce water losses, for instance by reducing activity or shifting to cover when ambient temperature becomes too high (Abdu et al. 2018; Fuller et al. 2016). These adjustments will become critical for the survival of organisms that may face increasing water scarcity in the future as a consequence of global changes in climate (Field et al. 2012; Mitchell et al. 2018; McKechnie 2019).

Individual space-use strategies become critical when animals face water scarcity. Most large herbivores living in arid and semi-arid environments worldwide only can find drinking water in sparsely distributed water sources such as water pans (Cain III et al. 2006; Cornélis et al. 2011; Espinosa et al. 2018; Gedir et al. 2016; Redfern et al. 2003; Reyna-Hurtado et al. 2012; Valls-Fox et al. 2018). These pans are highly seasonal, and their location strongly constrains animal movement during the dry season (Loarie et al. 2009; Valls-Fox et al. 2018). Individuals must leave the vicinity of water to make foraging trips and then return to water. Prior research has focused on understanding how the distance between water and forage ultimately constrains the movements of individuals (Cain III et al. 2012; Chamaillé-Jammes et al. 2013).

Environmental conditions during these foraging trips, and in particular temperature, also could constrain individual movements. This would be true particularly in environments where temperature already is generally high. Exposure to high temperatures and high water losses due to passive (respiratory water losses) or active evaporative cooling (e.g. panting, sweating; Robbins and Parker 2017) during foraging trips will make them costly for thermo-hydroregulation (Rozen-Rechels et al., 2019). We should therefore expect individuals to adjust the duration of the trips to the temperature they experience, with potential trade-offs for feeding. We also might expect, 
in places where a diel cycle in temperature is significant, that individuals account for these diel variations and adjust the timing of trips to minimize the risk of overheating and dehydration.

In this study, we test whether the temporal aspects of foraging trips of the African savanna elephant, Loxodonta africana (Cuvier, 1825), are influenced by environmental temperature. Foraging trips between visits to distant water sources during dry season are well documented in elephants (Chamaillé-Jammes et al., 2013; Polansky et al. 2015; Shannon et al. 2009; Thaker et al. 2019; Wato et al. 2018). Their thermal physiology also is well understood. The elephants' mass and volume, and the absence of sweat glands, make it difficult for them to lose heat, increasing the risk of overheating (Wright 1984; Wright and Luck 1984). Biophysical studies highlighted anatomical and morphological adaptation in elephants favoring heat dissipation through ear flapping (Koffi et al. 2014; Phillips and Heath 1992; Wright 1984) or sufficient passive evaporative cooling (Wright and Luck, 1984) through cracks in the skin (Lillywhite and Stein, 1987; Martins et al., 2018). Finescale behavioral adjustments such as shade-seeking, dust-bathing, or wetting, also could be critical for their physiology, especially under high water and thermal constraints when physiological adaptations are not suficient (Kinahan et al. 2007; Mole et al. 2016; Thaker et al. 2019). Overall, temperature-dependent physiological and small-scale behavioral adjustments generally are wellunderstood in elephants. What remains poorly known is whether other adjustments occur at larger scales, such as at the scale of entire foraging trips.

We test the hypothesis that temperature influences the timing and duration of elephants' dry season foraging trips in Hwange National Park, Zimbabwe. In Hwange, elephants visit waterholes periodically (every $24 \mathrm{~h}$ or $48 \mathrm{~h}$, sometimes $72 \mathrm{~h}$; Chamaillé-Jammes et al. 2013; VallsFox et al. 2018). We chose not to include the rainy season because surface water is widespread and its availability does not constraint elephant movement as it does during the dry season (ChamailléJammes et al. 2013; Valls-Fox 2015). We test the hypothesis that ambient temperature constrains the decision of continuing, or stopping a trip, and we predict that longer trips would be made under relatively colder conditions. Regardless of trip duration, the timing of elephants' visit to waterholes 
is usually concentrated around nightfall (Valeix et al. 2007; Valls-Fox 2015), leading to the surprising observation that elephants travel at high speed under the afternoon's sun (ChamailléJammes et al., 2013; Thaker et al., 2019). We test the hypothesis that this timing allows elephants to minimize the average temperature experienced during the foraging trip from and to water.

\section{MATERIAL AND MethodS}

Study area

The study was carried out in the eastern region of Hwange National Park, Zimbabwe $\left(\sim 26.9^{\circ} \mathrm{E}\right.$ $\left.18.8^{\circ} \mathrm{S}\right)$. The area is characterized by relatively level terrain (alt. $1000-1100 \mathrm{~m}$ asl) and the vegetation is typical of semi-arid savanna. Average annual precipitation is ca. $600 \mathrm{~mm}$ with high inter-annual variations (Chamaillé-Jammes et al. 2006). Rainfall is highly seasonal: about $80 \%$ of the annual rainfall occurs between November and April. Natural depressions and dams fill up with water during the rainy season and water thus is unlikely to constrain foraging during this season. In most of the park, there are no rivers, and those found in the north and south of the park only flow for a few days after heavy rains. Some pools keep water for longer, but as for all natural water pans, they gradually dry up during the dry season (Chamaillé-Jammes et al. 2007). At the end of the dry season in the study area, surface water only can be found at artificial waterholes into which groundwater is pumped continuously. Water-dependent species such as elephants must undertake foraging trips to and from these waterholes (Chamaillé-Jammes et al., 2013). This creates local forage depletion near waterholes and, in the long-run, habitat change, i.e. a piosphere (Andrew 1988). Here, vegetation cover increases with distance to water up to several kilometers away from these waterholes (Chamaillé-Jammes et al. 2009). In the study area, the locations are known of all artificial waterholes and large natural pans that retain water until at least June.

\section{Thermal conditions across seasons}

Data sampling was carried out during the 2013 dry season, from June 13th (when the elephants had settled in their dry season home-range) until October $23^{\text {rd }}$, when the elephants dispersed again after 
the first significant storm. We focused on the elephants' foraging trips that occurred during three periods of the dry season as defined based on changes in water availability (Valls-Fox et al. 2018). The first period covered the early cold-dry season (13 June to 7 July; mean daily temperature $\pm S E$ : $13.1 \pm 0.4^{\circ} \mathrm{C}$, from 105 water pans at the start of the period to 97 at the end). The following periods covered the mid-dry season (5 August to 10 September; $18.0 \pm 0.3^{\circ} \mathrm{C}$, from 72 to 63 pans), and the hot-dry season (11 September to 23 October; $23.7 \pm 0.2^{\circ} \mathrm{C}$, from 62 to 57 pans). We excluded the end of the cold-dry season because of the rapid decrease of the number of water pans during that period of time (from 92 to 73 pans; Valls-Fox et al. 2018). Cold-dry season was included as a matter of comparison with warm seasons during which we expect thermal constraints to be the highest (Supplementary Data SD1). At the same time, air temperature also was measured every hour at the Hwange LTER-CNRS weather station $\left(26.952^{\circ}\right.$ E $18.731^{\circ} \mathrm{S}$; Supplementary Data SD2). Whatever the season, temperatures were maximal around $14: 00 \mathrm{~h}-15: 00 \mathrm{~h}$ and reached up to $27.6^{\circ} \mathrm{C}$ during the cold-dry season, $32.3^{\circ} \mathrm{C}$ during the mid-dry season, and $38.1{ }^{\circ} \mathrm{C}$ during the hot-dry season (Supplementary Data SD2).

\section{Elephant movement data}

In November 2012, 13 adult female elephants belonging to different family herds were equipped with GPS collars recording one location every $30 \mathrm{~min}$ (every $5 \mathrm{~min}$ from 11 October to 14 October). We retained data from 8 collars for which the occasional failures in acquiring locations occurred when the elephant was too far away from water to have been able to reach water and be back at the next acquired location. This enabled us to reliably identify visits to water. Note that GPS collars were programmed to collect one location every 30 minutes and the average time spent by elephant family herds at a waterhole is $20 \mathrm{~min}$. Trips were removed from the dataset if two conditions were fulfilled: (a) the gap lasted more than $1 \mathrm{~h}$ and (2) the gap occurred when the elephant was sufficiently close to water for it to travel back and forth in a straight line at a speed below $1 \mathrm{~m} . \mathrm{s}^{-1}$. By using a speed criterion, trips with small gaps in the GPS sequence occurring far away from waterholes were maintained in the dataset. An individual was considered to have visited a waterhole 
if its GPS track intersected a buffer of $200 \mathrm{~m}$ radius, or if an individual could have reached water between two successive GPS locations based on its speed and direction (see Valls-Fox et al. 2018 appendices for methods and validation). A foraging trip was defined as the movement path covered between two consecutive visits to a waterhole (see Valls-Fox et al. 2018 for further information about the extraction of trips from trajectory data). During the 2013 dry season, we identified 901 trips. In this study, direct observations and camera trap records of the studied herds suggest that they were made of 5-17 individuals, typically comprising about $2-8$ adult females and their immature offspring, and occasionally one or a few adult males.

Due to the strong multimodality in trip duration (Fig. 1A), and as in previous studies (Chamaillé-Jammes et al. 2013; H. Valls-Fox et al. 2018), we divided the trips into four categories named after their average values (Fig. 1A): trips that lasted less than 12 hours (4.5 hours in average in our data); $24 \mathrm{~h}$ long trips ( 12 - $36 \mathrm{~h}$ long); 48 hours long trips (from $36-60 \mathrm{~h}$ long); and $72 \mathrm{~h} \mathrm{(} \geq$ $60 \mathrm{~h}$ ). We focused on trips of the $24 \mathrm{~h}, 48 \mathrm{~h}$, and $72 \mathrm{~h}$, categories, as we considered that trips lasting $12 \mathrm{~h}$ or less were too short to be constrained by the risk of overheating or dehydration, or that adjustments would occur at a smaller scale than the one considered here. Ultimately, we analyzed data from 535 trips (Fig. 1A).

We analyzed how elephants timed their departure according to sunset by fitting the linear regression between the duration of the trip and time elapsed since sunset. Departure time was 0 hour if it occurred at sunset, positive if departure occurred within $12 \mathrm{~h}$ after sunset and negative if departure occurred within $12 \mathrm{~h}$ before sunset. Sunset time has been estimated for the mean coordinates of Hwange National Park $\left(26.9^{\circ} \mathrm{E} 18.8^{\circ} \mathrm{S}\right)$ using the algorithms provided by the National Oceanic and Atmospheric Administration (NOAA) with the "maptools" package in R (Bivand and Lewin-Koh 2019).

Testing whether departure time affects temperature experienced during the trips We used departure times from waterholes, corrected by sunset time, as indicators of the timing of the trips. Note that the departure time of a trip usually is very close in time to the arrival time from 
the previous trip, as elephants do not stay long at waterholes (often $<30 \mathrm{~min}$ ). Departure time was estimated using the timestamp of the first location record of the trip.

We computed the average temperature experienced during each trip as an indicator of thermal conditions. To determine the importance of departure time, we calculated the average temperature for shifted departure times. We shifted the departure time by $-12 \mathrm{~h},-11 \mathrm{~h}, \ldots,+11 \mathrm{~h}$ and repeated the computation of the average temperature. For each trip, we thus obtained the 'real' average temperature experienced, as well as 24 values of the average temperature that could have been experienced if the trip had started at a different time of the day (hereafter called an alternative trip). We did not use the maximal temperature because in most cases - and because trip duration was large relative to the shifts imposed - the time of the maximum temperature experienced during the actual trip was included in the shifted trips, and there was therefore no difference between the maximum temperature experienced during the actual trip and the maximum temperature of any of the shifted trips. We modeled how the average temperature of alternative trips changed according to departure time using generalized additive mixed models. In these models, the average temperature experienced during the trip was the response variable and departure time a fixed predictor transformed using a cyclic cubic spline because departure time is a circular variable. The model fitted 9 splines, one for each trip type $(24,48,72 \mathrm{~h})$ and season (cold-dry, mid-dry, hot-dry) combination. The identity of each elephant was included as a random effect on the intercept. For each trip type, season and hour of the day, we extracted the predicted average temperature experienced during the trip $\left(\mathrm{T}_{\text {predict }}\right)$.

To test if there were more trips at times that allowed elephants to experience lower average trip temperature, we modeled the number of trip departure per hour as a function of $\mathrm{T}_{\text {predict }}$ for that departure hour. In other words, we tested if hours with most departures also are hours with the lowest $\mathrm{T}_{\text {predict. }}$ We did this by fitting a generalized linear model with a Poisson distribution for errors, for each one of the 9 predicted splines with the three-way interaction (temperature $\times$ season $\times$ trip type). 


\section{Testing whether temperature experienced early in the trip affects trip duration}

For each trip, we calculated the average temperature during the first 12 hours. We considered that these measures could be good proxies of the thermal conditions that would influence the decision of returning to a waterhole and thus carrying out a $24 \mathrm{~h}$ trip, or pursuing the trip and undertaking a longer trip ( $48 \mathrm{~h}$ or more). We modeled the probability of carrying out a $24 \mathrm{~h}$ trip (vs. a longer trip) according to two-way interaction of the average temperature during the first 12 hours, and the season, with a logistic regression using generalized linear models with a binomial error and the elephant identity as a random effect on the intercept. In the same way, we analyzed how average temperature during the first 24 hours of a trip would affect the probability of undertaking a $48 \mathrm{~h}$ trip v. a longer trip with another logistic regression. All statistical analyses were carried out using the R software version 3.4.4 (R Core Team, 2018) and the lme4 (Bates et al. 2015), and mgcv (Wood 2017) packages.

\section{Ethical note}

All necessary permits for the study were obtained from the appropriate agency (Zimbabwe Parks and Wildlife Management Authority, permits 23(1)(c) (ii)17/2009; 23(1)(c) (ii) 01/2010; 23(1)(c) (ii)05/2011). Permit applications are reviewed by an ad hoc committee that considers ethical and animal welfare issues. Immobilization and collaring was carried out specifically for this study by an experienced personnel who is granted authorization to immobilize and collar elephants by the Veterinary Services of Zimbabwe. All operations were carried out under the supervision of a Zimbabwe Parks and Wildlife Management Authority ranger. Each collar weighed approximately $13 \mathrm{~kg}$, less than $0.01 \%$ of animal body weight.

\section{RESULTS}

The general timing of trip departure is presented in Fig. 1B and 1C. Most trips started around sunset, i.e. between 18:00 and 20:00, and very few in the late night or early morning, i.e. between 03:00 and 10:00 (Fig. 1B). The duration of trips was adjusted so that arrival and departure of the next trip occurred around sunset: when individuals left earlier (later) they undertook longer (shorter) trips 
(Fig. 1C, trip category $\times$ corrected departure time: $F_{2,522}=8.1, p=0.0003$; slope estimated for $24 \mathrm{~h}$ trip types: $-0.48 \pm 0.06$; for $48 \mathrm{~h}$ trip types: $-0.33 \pm 0.10$; for $72 \mathrm{~h}$ or longer trips: $-1.32 \pm 0.23$ ). This explains the clear multimodal distribution of trip duration roughly lasting 24,48 or $72 \mathrm{~h}$ (Fig. 1A).

\section{Departure time selection according to potential thermal conditions}

In the case of $24 \mathrm{~h}$ and $48 \mathrm{~h}$ trip types, trips starting at sunset or slightly after sunset are those for which the average temperature is the lowest (Fig. 2). Most departures occurred around sunset, i.e., between 15:00h $-20: 00 \mathrm{~h}$, throughout the dry season and for all trip types. The relationship between predicted temperature and hour of departure was not significant for $72 \mathrm{~h}$-long trips, but sample size was very limited (5 during the Cold-Dry season, 20 during the Mid-Dry, 6 during the Hot-Dry). We therefore excluded 72h-long trips from further analyses. Most trips departed at hours allowing lower experienced trip temperature as shown by the negative relationship between the number of trips observed to start at a specific time and $\mathrm{T}_{\text {predict }}$ (Fig. 3). The relationship was significant for $24 \mathrm{~h}$ and $48 \mathrm{~h}$ trips throughout the dry season $\left(\mathrm{T}_{\text {predict }} \times\right.$ season $\times$ trip type: $\chi^{2}{ }_{4}=17.9, p=0.0001$; Fig. 3, details of the results in Supplementary Data SD3).

\section{Probability of undertaking a longer trip according to temperature}

The probability of undertaking a 24-hour trip rather than a longer trip increased when the average temperature during the first 12 hours of the trip was higher $\left(\chi^{2}{ }_{1,3}=12.4, p=0.0004\right)$, for all three periods of the dry season (temperature $\times$ season: $\chi^{2} 2,7=2.5, p=0.29$; season: $\chi^{2} 2,5=3.1, p$ $=0.21$ ). The probability of undertaking a 48-hour trip rather than a longer one was significantly the lowest during the mid-dry season and highest during the hot-dry season $\left(\chi^{2} 2,4=7.4, p=0.03\right.$; multiple comparisons provided in Supplementary Data S4), regardless of thermal conditions during the first $24 \mathrm{~h}$ of the trip (temperature $\times$ season: $\chi^{2}{ }_{2,7}=0.2, p=0.93$; temperature: $\chi^{2}{ }_{1,5}=0.91, p=$ $0.34)$.

\section{DISCUSSION}

Our study shows that temperature influences decisions about when to move, and for how long. This completes past studies that highlighted the impact of thermal conditions on activity 
levels and habitat selection (Kinahan et al. 2007; van Beest et al. 2012; Fuller et al. 2016; Mole et al. 2016; Thaker et al. 2019). We show that the timing and duration of elephant foraging trips are partly determined by temperature: most trips start at an hour that allows elephants to experience a lower average temperature during the trip. In addition, when the beginning of the trip is warmer, the trip is more likely to be shorter.

The general, and distinctive, timing of elephants' visits at waterholes around nightfall between 18:00 and 20:00, or sometimes a few hours earlier when elephant numbers at waterholes increases during dry years (Valeix et al., 2007), at first appears counter-intuitive. To reach waterholes at the end of the day elephants walk at relatively high speed (Chamaillé-Jammes et al. 2013) under the afternoon sun. However, we show that this timing allows elephants to achieve lower average trip temperatures than other departure times. This arises because trip duration is rarely exactly $24 \mathrm{~h}$ or $48 \mathrm{~h}$ (Fig. 1): when departing at sunset, trips lasting less than $24 \mathrm{~h}$ or $48 \mathrm{~h}$ reduce the time spent at above-average temperature while traveling (late afternoon; Supplementary Data SD2); in such cases elephants could then carry out a short trip of a few hours, during which temperatures are less important, before leaving at sunset for another long trip; trips lasting more than $24 \mathrm{~h}$ or $48 \mathrm{~h}$ could have allowed elephants to forage more, or further away from water, while limiting their exposure to high temperatures because the extra-time is spent at below-average temperature (early night; Supplementary Data SD2).

Surprisingly, the coincidence of trip departure with sunset also was evident in the colddry period. If this specific timing emerged to avoid overheating, as we assumed, we would have expected it to be less marked, if present at all, during the cold-dry period. We are aware that our results cannot give a proper explanation to that result. We offer three hypotheses: first, there could be no cost associated with such timing. Although less beneficial, we suppose that a behavioral pattern would not change if it is not costly, which could thus lead to its establishment during the entire dry season. Second, solar radiation and temperature could remain a constraint during the cold dry period (Wright 1984; Wright and Luck 1984). Third, nights during the cold-dry season could be 
too cold, particularly close to water (temperature sometimes falls below $0^{\circ} \mathrm{C}$; Valls-Fox 2015). In Hwange National Park, water pans often are located in vleis, i.e. depression in the landscape where humidity level is higher and vegetation that could stop the wind is sparse. Temperatures at night often are much lower in water pan areas than elsewhere. Therefore, it is possible that traveling to warmer woodlands at night would limit heat loss and thus reduce the costs of keeping warm for elephants in the cold-dry season, despite the large thermal inertia associated with their large body size.

Despite the fact that the timing of visits to waterholes reduces the average temperature experienced during the whole trip, it seems that it puts elephants at risk of overheating due to the final march towards waterholes undertaken in the afternoon heat. We argue that this risk may be lower than expected because elephants can quickly cool down at the waterhole by drinking, bathing, wallowing, or spraying themselves (Dunkin et al. 2013; Mole et al. 2016), thanks to the water retention properties of their skin structure (Lillywhite and Stein 1987; Martins et al. 2018).

The timing of visits to waterholes described here is not specific to Hwange National Park. Visiting waterholes at nightfall appears to be common in elephant populations in southern and eastern Africa (Table 1). Some of these studies suggest that such timing is especially marked when temperature is high and during the hot-dry season. This supports our assertion that temperature is the underlying driver of this timing. Such general observation spanning several distant populations strongly suggests that this timing is not a "cultural" behavioral trait developed in isolation in Hwange National Park (Fishlock et al. 2016), but rather that it is a flexible behavior that can be rapidly adjusted, or a behavior under relatively strong selection pressure in these arid and semi-arid environments. Individuals that timed their trips on sunset might have survived better on average. The absence of modulation of this pattern during the coldest season would argue for a selected behavior.

We also show that temperature similarly affects, beyond the timing of trips, the duration of these trips. For example, long foraging trips (48 $\mathrm{h}$ long or more) are avoided with increasing 
temperatures. These results could have important implications for the ecology of this population of elephants. First, if temperature reduces the duration of the trip, it limits the ability of elephants to forage far away from water (Chamaillé-Jammes et al. 2013). Resources are scarcer closer to water due to a higher density of elephants (Chamaillé-Jammes et al. 2009), which implies that under high thermal constraints, individuals only would have access to a limited amount of foraging resources. High temperature might then influence foraging behaviors. Constraints imposed by food distribution (i.e. strong forage depletion near waterholes) might force individuals to make long trips, which could explain why the $48 \mathrm{~h}$ trips still persist during the hottest part of the dry season. We tentatively suggest that these $48 \mathrm{~h}$ trips during the dry season may create a water debt, whereas $24 \mathrm{~h}$ trips are probably less beneficial for foraging but maintain an adequate water balance. This study also ignores the potential role of very short trips ( 5 hours long in average, shorter than 12 hours) which could compensate long trips in terms of water balance and heat avoidance.

Finally, our results add to the literature about the cognitive capacities of elephants. Previous studies have shown that elephants are able to memorize the locations of waterholes and navigate back to them without searching (Polansky et al., 2015; Presotto et al. 2019; Wato et al., 2018). Here, we show, implicitly, that they integrate memorized spatial information with expected travel time, likely adjusting speed of travel, to arrive at waterholes near nightfall. Obviously, estimating the accuracy of this time-space integration is beyond the scope of this paper.

This study lacks considerations of the micro-habitats used by individuals during their trips. By shifting their trajectories to cooler micro-habitats (more shade, thicker vegetation), individuals might be able to buffer the effects of heat (Huey et al. 2012). By doing so, individuals might efficiently avoid overheating during their afternoon race to water. Such behavior might mitigate and help to understand a significant part of the variability in the pattern described herein (Fig. 1B). A description of the thermal micro-habitats landscape would be useful to estimate the availability and use of temperature-buffering opportunities, as would be the use of accurate recordings of actual temperature experienced by elephants (for instance using black bulbs on collars; 
Fuller et al. 2014). In the context of global warming, there is an urgent need to understand the effect of temperature on animals. Movement is a key aspect of temperature regulation, and how individuals adjust their movement strategies to temperature fluctuations has rightly become a subject of interest (Fuller et al. 2016; Sears et al. 2016; Rakowski et al. 2019). This effort should be pursued, and future work should address how temperature affects linkages between time and space in animal movement, as movement is by definition a complex multi-scale process.

\section{ACKNOWLEDGEMENTS}

We thank the Director General of the Zimbabwe Parks and Wildlife Management Authority and the Research Council of Zimbabwe for providing the opportunity to carry out this research. Funding was provided by grant SAVARID ANR-11-CEPS-003 and LANDTHIRST ANR-16 CE02-0001-01 of the French 'Agence National de la Recherche'. This work was carried out within the framework of the Zone Atelier Hwange-Hwange LTSER (www.za hwange.cnrs.fr) and under the auspices of the Research Platform "Production and Conservation in Partnership" (www.rp-pcp.org). We thank R. Reyna-Hurtado, A. Shrader, and two anonymous reviewers, for their comments.

\section{Data AVAILABILITY Statement}

The datasets analyzed during the current study are available from the corresponding author on reasonable request.

\section{AUTHORS' CONTRIBUTIONS}

DRR and SCJ designed the study, which was facilitated by CTM. HVF collected and prepared the data. DRR analyzed the data and led the writing of the manuscript, with significant contributions from all authors.

\section{SUPPLEMENTARY DATA}

Supplementary Data SD1.-- Inter-seasonal temperature variability

Supplementary Data SD2.-Daily temperature variations according to the season 
Supplementary Data SD3. - Estimated coefficients of the model fitting the number of observed trips as a function of the average temperature experienced during the trip predicted from the hour of departure.

Supplementary Data SD4.--Multiple comparisons of the probability of undertaking a 48h trip over a longer one according to the season.

\section{LITERATURE CITED}

Abdu, S., A. E. McKechnie, A. T. K. LeE, And S. J. Cunningham. 2018. Can providing shade at water points help Kalahari birds beat the heat? Journal of Arid Environments 152:21-27.

ANDREW, M. H. 1988. Grazing impact in relation to livestock watering points. Trends in Ecology \& Evolution 3:336-339.

AyEnI, J. S. O. 1975. Utilization of waterholes in Tsavo National Park (East). African Journal of Ecology 13:305-323.

BATES, D., M. MÄCHLER, B. BOLKER, AND S. WALKER. 2015. Fitting linear mixed-effects models using lme4. Journal of Statistical Software 67:1-48.

VAn BeEst, F. M., B. VAn MoOrTer, And J. M. MiLner. 2012. Temperature-mediated habitat use and selection by a heat-sensitive northern ungulate. Animal Behaviour 84:723-735.

BIVAND, R., AND N. LEWIN-KOH. 2019. maptools: tools for handling spatial objects. R package version 0.9-5. $<$ https://CRAN.R-project.org/package=maptools $>$. Accessed on 14 Oct, 2019.

Cain III, J. W., P. R. Krausman, S. S. Rosenstock, And J. C. Turner. 2006. Mechanisms of thermoregulation and water balance in desert ungulates. Wildlife Society Bulletin 34:570581.

CAIN III, J. W., N. OWEn-SMith, AND V. A. MaCAnDZA. 2012. The costs of drinking: comparative water dependency of sable antelope and zebra. Journal of Zoology 286:58-67.

Chamaillé-Jammes, S., H. Fritz, And H. Madzikanda. 2009. Piosphere contribution to landscape heterogeneity: a case study of remote-sensed woody cover in a high elephant density landscape. Ecography 32:871-880. 
Chamaillé-Jammes, S., H. Fritz, AND F. Murindagomo. 2006. Spatial patterns of the NDVIrainfall relationship at the seasonal and interannual time scales in an African savanna. International Journal of Remote Sensing 27:5185-5200.

Chamaillé-Jammes, S., H. Fritz, AND F. MurindagOMO. 2007. Climate-driven fluctuations in surface-water availability and the buffering role of artificial pumping in an African savanna: Potential implication for herbivore dynamics. Austral Ecology 32:740-748.

Chamaillé-Jammes, S., G. Mtare, E. Makuwe, AND H. Fritz. 2013. African elephants adjust speed in response to surface-water constraint on foraging during the dry-season. PLoS ONE 8:e59164.

Cornélis, D., S. Benhamou, G. Janeau, N. Morellet, M. Ouedraogo, And M.-N. DE VISSCHER. 2011. Spatiotemporal dynamics of forage and water resources shape space use of West African savanna buffaloes. Journal of Mammalogy 92:1287-1297.

DAVIS, J. R., AND D. F. DENARDO. 2009. Water supplementation affects the behavioral and physiological ecology of Gila monsters (Heloderma suspectum) in the Sonoran Desert. Physiological and Biochemical Zoology 82:739-748.

Dunkin, R. C., D. WiLson, N. WAY, K. Johnson, AND T. M. WiLliams. 2013. Climate influences thermal balance and water use in African and Asian elephants: physiology can predict drivers of elephant distribution. Journal of Experimental Biology 216:2939-2952.

Espinosa, M. I., N. Gouin, F. A. SQueO, D. LÓPEZ, AND A. BerTin. 2018. Landscape connectivity among remnant populations of guanaco (Lama guanicoe Müller, 1776) in an arid region of Chile impacted by global change. PeerJ 6:e4429.

Field, C. B., V. BARros, T. F. Stocker, AND Q. DAHE. 2012. Managing the risks of extreme events and disasters to advance climate change adaptation: special report of the intergovernmental panel on climate change. Cambridge University Press.

Fishlock, V., C. CALDWELl, AND P. C. LEE. 2016. Elephant resource-use traditions. Animal Cognition 19:429-433. 
Fuller, A., R. S. Hetem, S. K. Maloney, AND D. Mitchell. 2014. Adaptation to heat and water shortage in large, arid-zone mammals. Physiology 29:159-167.

Fuller, A., D. Mitchell, S. K. Maloney, AND R. S. Hetem. 2016. Towards a mechanistic understanding of the responses of large terrestrial mammals to heat and aridity associated with climate change. Climate Change Responses 3:10.

Gedir, J. V., J. W. Cain III, P. R. Krausman, J. D. Allen, G. C. DufF, And J. R. Morgart. 2016. Potential foraging decisions by a desert ungulate to balance water and nutrient intake in a water-stressed environment. PloS ONE 11:e0148795.

GERSON, A. R., ET AL. 2019. The functional significance of facultative hyperthermia varies with body size and phylogeny in birds. Functional Ecology 33:597-607.

Gerson, A. R., E. K. Smith, B. Smit, A. E. McKechnie, And B. O. Wolf. 2014. The impact of humidity on evaporative cooling in small desert birds exposed to high air temperatures. Physiological and Biochemical Zoology 87:782-795.

GUY, P. R. 1976. Diurnal activity patterns of elephant in the Sengwa Area, Rhodesia. African Journal of Ecology 14:285-295.

HETEM, R. S., ET AL. 2010. Variation in the daily rhythm of body temperature of free-living Arabian oryx (Oryx leucoryx): does water limitation drive heterothermy? Journal of Comparative Physiology B 180:1111-1119.

Hetem, R. S., S. K. MAloney, A. Fuller, And D. Mitchell. 2016. Heterothermy in large mammals: inevitable or implemented? Biological Reviews 91:187-205.

Hothorn, T., F. BRETZ, AND P. WeSTFALl. 2008. Simultaneous inference in general parametric models. Biometrical Journal 50:346-363.

Huey, R. B., M. R. Kearney, A. Krockenberger, J. A. Holtum, M. Jess, and S. E. Williams. 2012. Predicting organismal vulnerability to climate warming: roles of behaviour, physiology and adaptation. Philosophical Transactions of the Royal Society of London B: Biological Sciences 367:1665-1679. 
KEMP, R., AND A. E. MCKeCHNIE. 2019. Thermal physiology of a range-restricted desert lark. Journal of Comparative Physiology B 189:131-141.

Kinahan, A. A., S. L. Pimm, And R. J. VAn Aarde. 2007. Ambient temperature as a determinant of landscape use in the savanna elephant, Loxodonta africana. Journal of Thermal Biology $32: 47-58$.

Koffi, M., Y. ANDREOPOUlOS, AND L. M. JIJI. 2014. The role of pinnae flapping motion on elephant metabolic heat dissipation. Journal of Heat Transfer 136:101101.

LILLYWHITE, H. B., AND B. R. STEIN. 1987. Surface sculpturing and water retention of elephant skin. Journal of Zoology 211:727-734.

LOARIE, S. R., R. J. V. AARDE, AND S. L. PIMM. 2009. Fences and artificial water affect African savannah elephant movement patterns. Biological Conservation 142:3086-3098.

MARTINS, A. F., ET AL. 2018. Locally-curved geometry generates bending cracks in the African elephant skin. Nature Communications 9:3865.

McKeChnie, A. E. 2019. Physiological and morphological effects of climate change. Pp. 120-133 in Effects of climate change on birds. 2nd ed. (P. O. Dunn and A. P. Møller, eds.). Oxford University Press, Oxford.

McKinley, M. J., D. Martelli, G. L. Pennington, D. Trevaks, And R. M. McAllen. 2018. Integrating competing demands of osmoregulatory and thermoregulatory homeostasis. Physiology 33:170-181.

Mitchell, D., E. P. Snelling, R. S. Hetem, S. K. Maloney, W. M. Strauss, and A. Fuller. 2018. Revisiting concepts of thermal physiology: Predicting responses of mammals to climate change. Journal of Animal Ecology 87:956-973.

Mole, M. A., S. Rodrigues DÁraujo, R. J. van Aarde, D. Mitchell, And A. Fuller. 2016. Coping with heat: behavioural and physiological responses of savanna elephants in their natural habitat. Conservation Physiology 4:cow044. 
MuÑOZ-GARCIA, A., ET AL. 2016. Metabolic rate, evaporative water loss and thermoregulatory state in four species of bats in the Negev desert. Comparative Biochemistry and Physiology Part A: Molecular \& Integrative Physiology 191:156-165.

O’Connor, R. S., B. O. Wolf, R. M. Brigham, And A. E. McKechnie. 2017. Avian thermoregulation in the heat: efficient evaporative cooling in two southern African nightjars. Journal of Comparative Physiology B 187:477-491.

PhILliPS, P. K., AND J. E. HEATH. 1992. Heat exchange by the pinna of the African elephant (Loxodonta africana). Comparative Biochemistry and Physiology Part A: Physiology 101:693-699.

POLANSKY, L., W. KILIAN, AND G. WITTEMYER. 2015. Elucidating the significance of spatial memory on movement decisions by African savannah elephants using state-space models. Proceedings of the Royal Society B: Biological Sciences 282:20143042-20143042.

Presotto, A., R. FAyrer-Hosken, C. Curry, And M. MadDen. 2019. Spatial mapping shows that some African elephants use cognitive maps to navigate the core but not the periphery of their home ranges. Animal Cognition 22:251-263.

PuRdON, A., AND R. J. VAN AARDE. 2017. Water provisioning in Kruger National Park alters elephant spatial utilisation patterns. Journal of Arid Environments 141:45-51.

R CORE TEAM. 2018. R: language and environment for statistical computing. R Foundation for Statistical Computing, 2005; Vienna, Austria.

Rakowski, A. E., R. D. Elmore, C. A. Davis, S. D. Fuhlendorf, And J. M. Carroll. 2019. Thermal refuge affects space use and movement of a large-bodied galliform. Journal of Thermal Biology 80:37-44.

Redfern, J. V., R. Grant, H. Biggs, AND W. M. GetZ. 2003. Surface-water constraints on herbivore foraging in the Kruger National Park, South Africa. Ecology 84:2092-2107. 
Reyna-Hurtado, R., C. A. Chapman, S. Calme, And E. J. Pedersen. 2012. Searching in heterogeneous and limiting environments: foraging strategies of white-lipped peccaries (Tayassu pecari). Journal of Mammalogy 93:124-133.

RobBins, C. T., AND K. L. PARKER. 2017. Thermoregulation in ungulates. Pp. 161-182 in Bioenergetics of wild herbivores (R. J. Hudson and R. G. White eds). Chapman and Hall/CRC.. Boca Raton, Florida.

ROZEN-RECHELS, D., ET AL. 2019. When water interacts with temperature: Ecological and evolutionary implications of thermo-hydroregulation in terrestrial ectotherms. Ecology and Evolution 9:10029-10043.

SEARS, M. W., ET AL. 2016. Configuration of the thermal landscape determines thermoregulatory performance of ectotherms. Proceedings of the National Academy of Sciences 113:1059510600.

Shannon, G., W. S. Matthews, B. R. Page, G. E. Parker, And R. J. Smith. 2009. The affects of artificial water availability on large herbivore ranging patterns in savanna habitats: a new approach based on modelling elephant path distributions. Diversity and Distributions $15: 776-783$.

Thaker, M., P. R. Gupte, H. H. T. Prins, R. Slotow, And A. T. VAnaK. 2019. Fine-scale tracking of ambient temperature and movement reveals shuttling behavior of elephants to water. Frontiers in Ecology and Evolution 7:4.

TiEleman, B. I., AND J. B. Williams. 2002. Cutaneous and respiratory water loss in larks from arid and mesic environments. Physiological and Biochemical Zoology 75:590-599.

Tsalyuk, M., W. Kilian, B. ReIneKing, AND W. M. Getz. 2019. Temporal variation in resource selection of African elephants follows long-term variability in resource availability. Ecological Monographs 89:e01348.

VAleiX, M., S. Chamaillé-JAMMeS, AND H. FRITZ. 2007. Interference competition and temporal niche shifts: elephants and herbivore communities at waterholes. Oecologia 153:739-748. 
Valls-Fox, H., M. D. Garine-Wichatitsky, H. Fritz, AND S. Chamaillé-Jammes. 2018.

Resource depletion versus landscape complementation: habitat selection by a multiple central place forager. Landscape Ecology 33:127-140.

VALLS-FoX, H. V. 2015. To drink or not to drink? The influence of resource availability on elephant foraging and habitat selection in a semi-arid savanna. PhD Thesis, Université de Montpellier. Montpellier, France.

WATO, Y. A., ET AL. 2018. Movement patterns of African elephants (Loxodonta africana) in a semiarid savanna suggest that they have information on the location of dispersed water sources. Frontiers in Ecology and Evolution 6:167.

WEIR, J., AND E. DAVISON. 1965. Daily occurrence of African game animals at water holes during dry weather. Zoologica Africana 1:353-368.

Wood, S. N. 2017. Generalized additive models: an introduction with R. Chapman and Hall/CRC. Boca Raton, Florida.

Wright, P. G. 1984. Why do elephants flap their ears? South African Journal of Zoology 19:266269.

Wright, P. G., AND C. P. LUCK. 1984. Do elephants need to sweat? South African Journal of Zoology 19:270-274. 
Table 1 Timing of visits to waterholes in populations of African elephants.

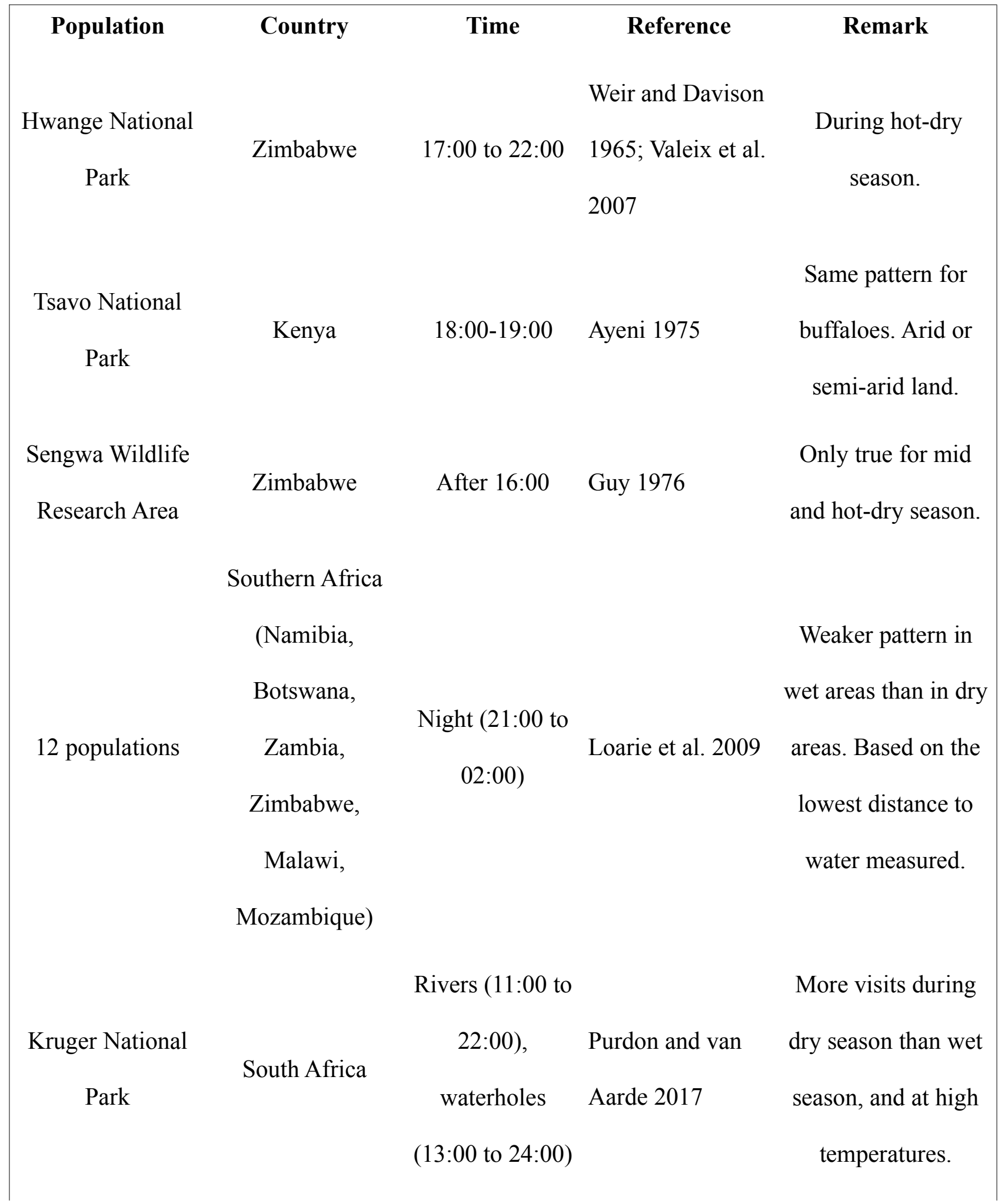


Estimations based on the hour with

Kruger National

Tsalyuk et al.

South Africa $\quad$ Around 19:00

2019

maximal preferences

Park

to short distances to

water 


\section{Figures legends}

Fig. 1.-A) Distribution of trip durations (in hours; excluding trips shorter than 12 hours). Black is for $24 \mathrm{~h}$ trips, dark gray is for $48 \mathrm{~h}$ trips and light gray is for $72 \mathrm{~h}$ or more longer trips. B) Distribution of trip departure time, corrected by sunset time, i.e., the difference to 0 calculates the number of hours to or since sunset, for each trip type. C) Trip durations (in hours) as a function of the departure time. Points are for each trip, black and grey lines are for predicted relationship between the duration of the trip and the corrected time of departure for each trip duration category with a linear mixed model with the elephant identification as a random effect (trip category $\times$ corrected departure time: $F_{2,507}=7.7, p=0.0005$ ). Red lines are showing the 24 hours, 48 hours, and 72 hours, trips. The shaded square shows the night time period.

Fig. 2. - Predicted variations of mean temperatures experienced during trips (upper panels), across all possible hours of departure (difference to sunset), for each for each trip type (24h, 48h, $72 \mathrm{~h}$ ) and each period of the dry season (Cold-dry, Mid-dry and Hot-dry). Estimates were obtained from generalized additive models (upper panels), and should be compared with the distribution of counts of actual departures for each hour of the day (lower panels; Fig. 3). Temp is for temperature. Plain lines are mean predicted temperatures, dashed lines are $95 \%$ confidence intervals. The significance of smooth-terms (difference to 0 which is a linear relationship) from generalized additive models are indicated with symbols: NS $=$ non-significant, $\uparrow \mathrm{p}<0.10, *=\mathrm{p}<0.05, * * \mathrm{p}<0.01, * * * \mathrm{p}<$ 0.001. The number of actual trips $\mathrm{n}$ in each case are indicated in each histogram.

Fig. 3. - Number of trips in relation to $T_{\text {predict, }}$ for each trip type $(24 \mathrm{~h}, 48 \mathrm{~h}, 72 \mathrm{~h})$ and each period of the dry season (Cold-dry, Mid-dry and Hot-dry). 
Figure 1
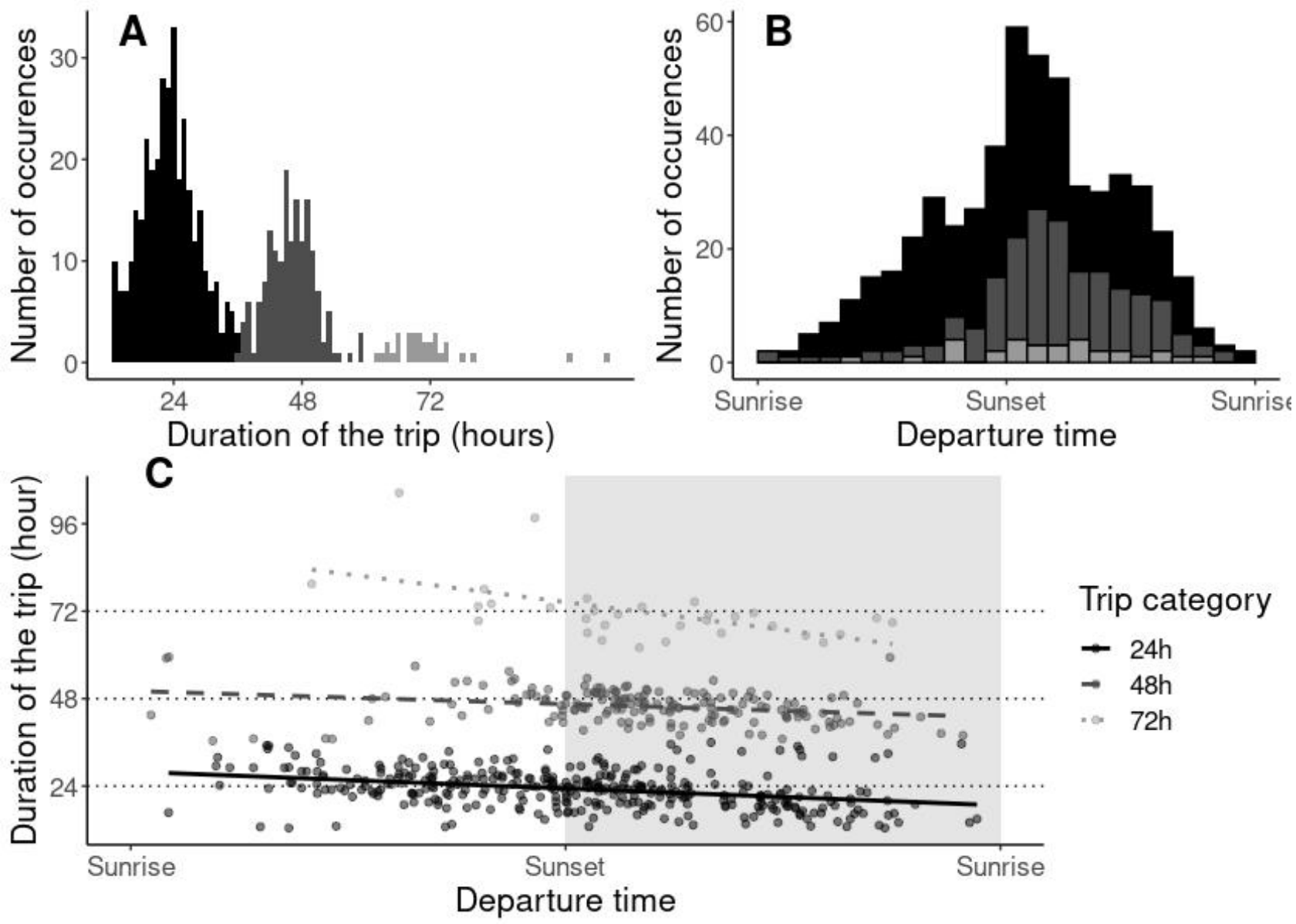
Figure 2
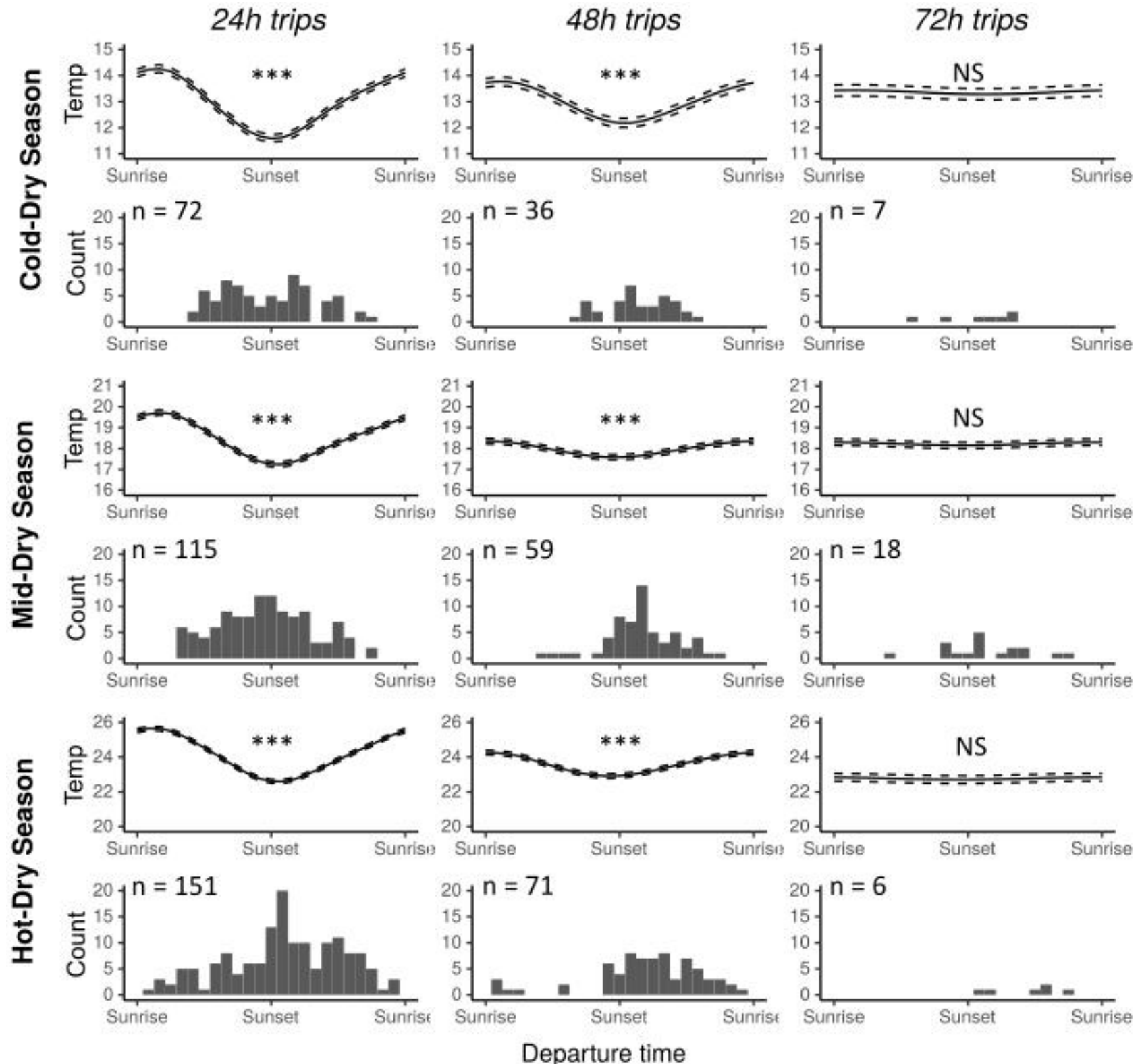

Departure time 
Figure 3

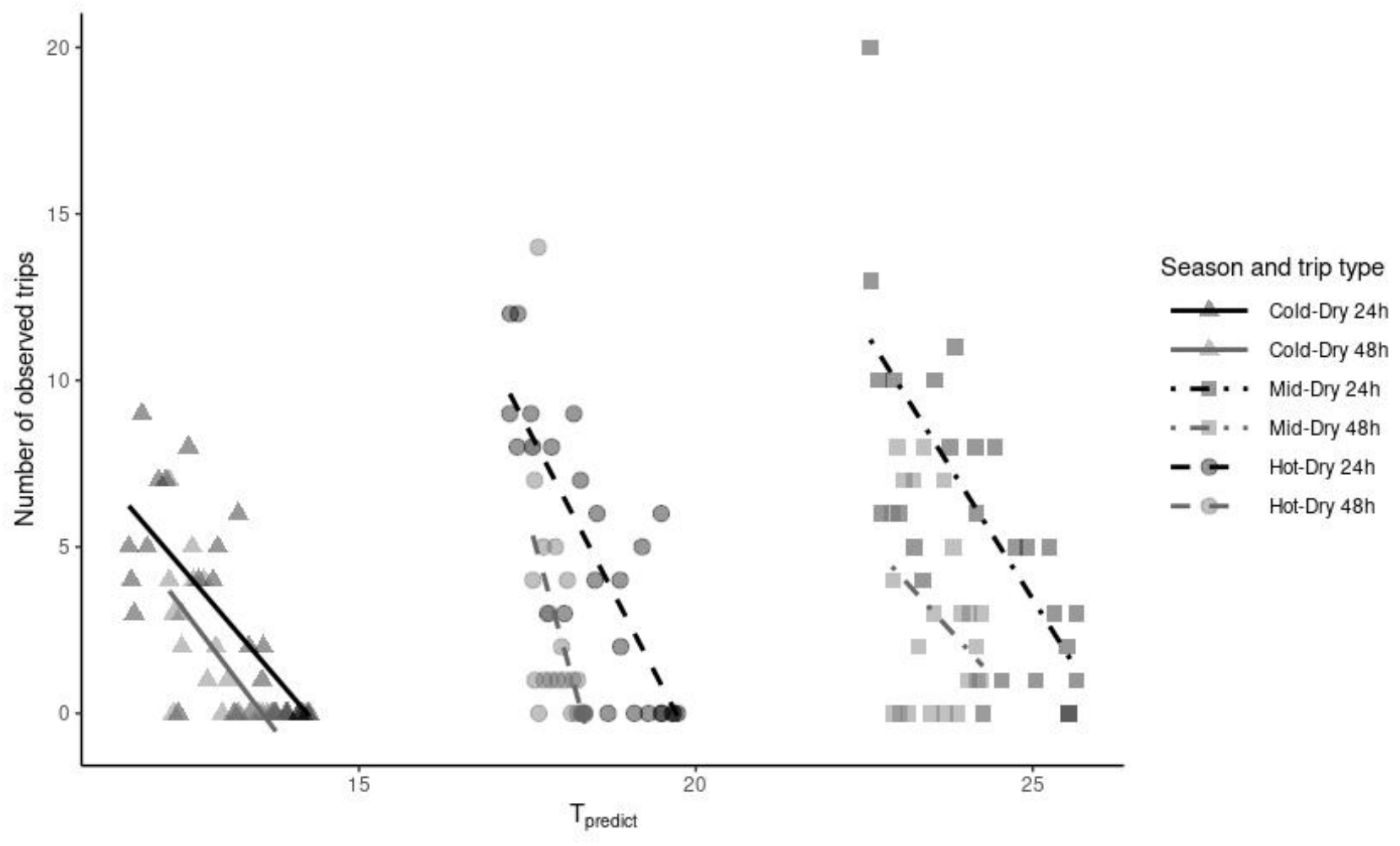


Supplementary Data SD1 Differences of temperature according to the season. The black line stands for the median.

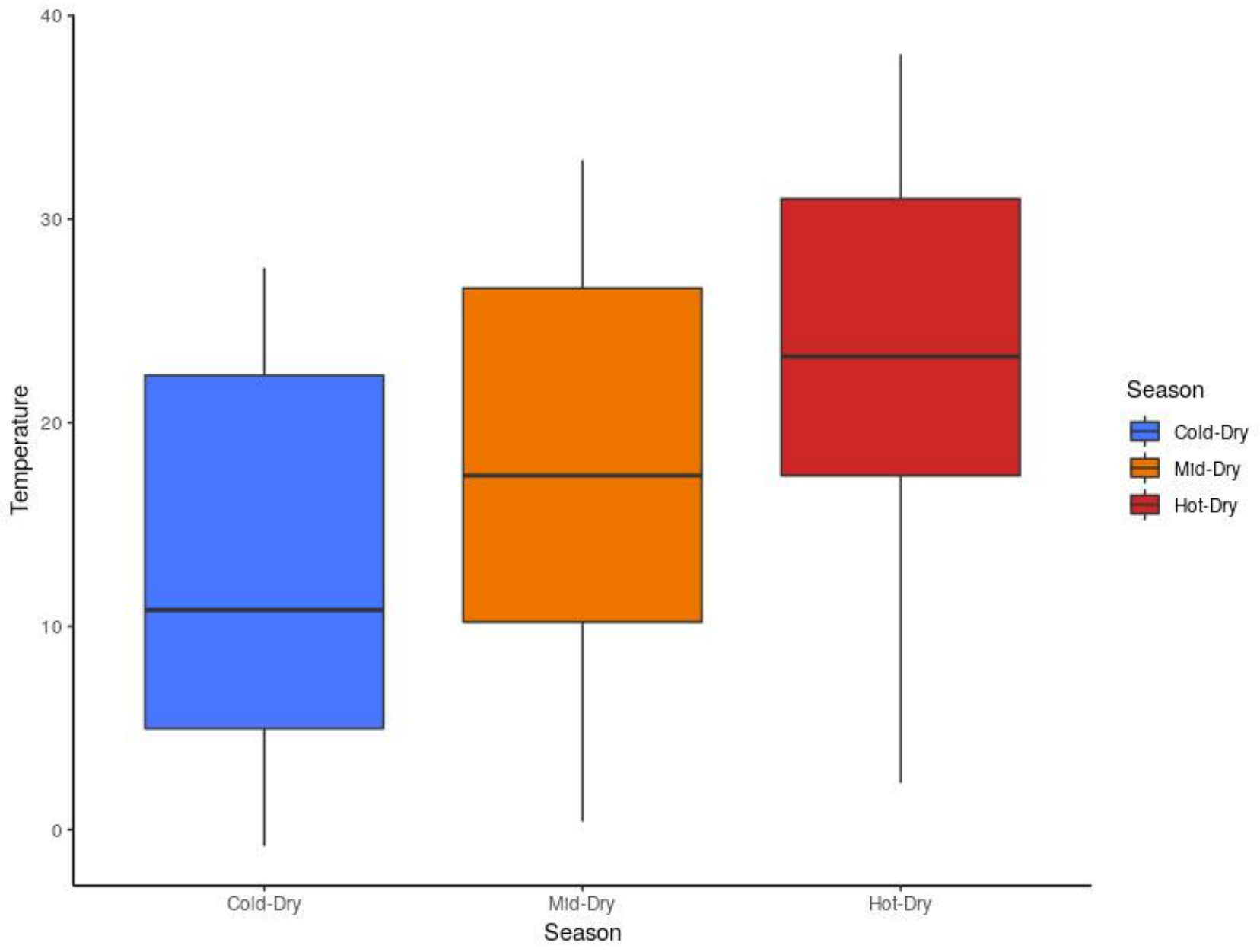


Supplementary Data SD2 Nycthemeral variations of temperature according to the season. Points are for average calculated in hour bins, errorbars are for standard deviations. Lines are loess fit of the variations on raw data. Vertical lines indicate the average sunset time for each season.

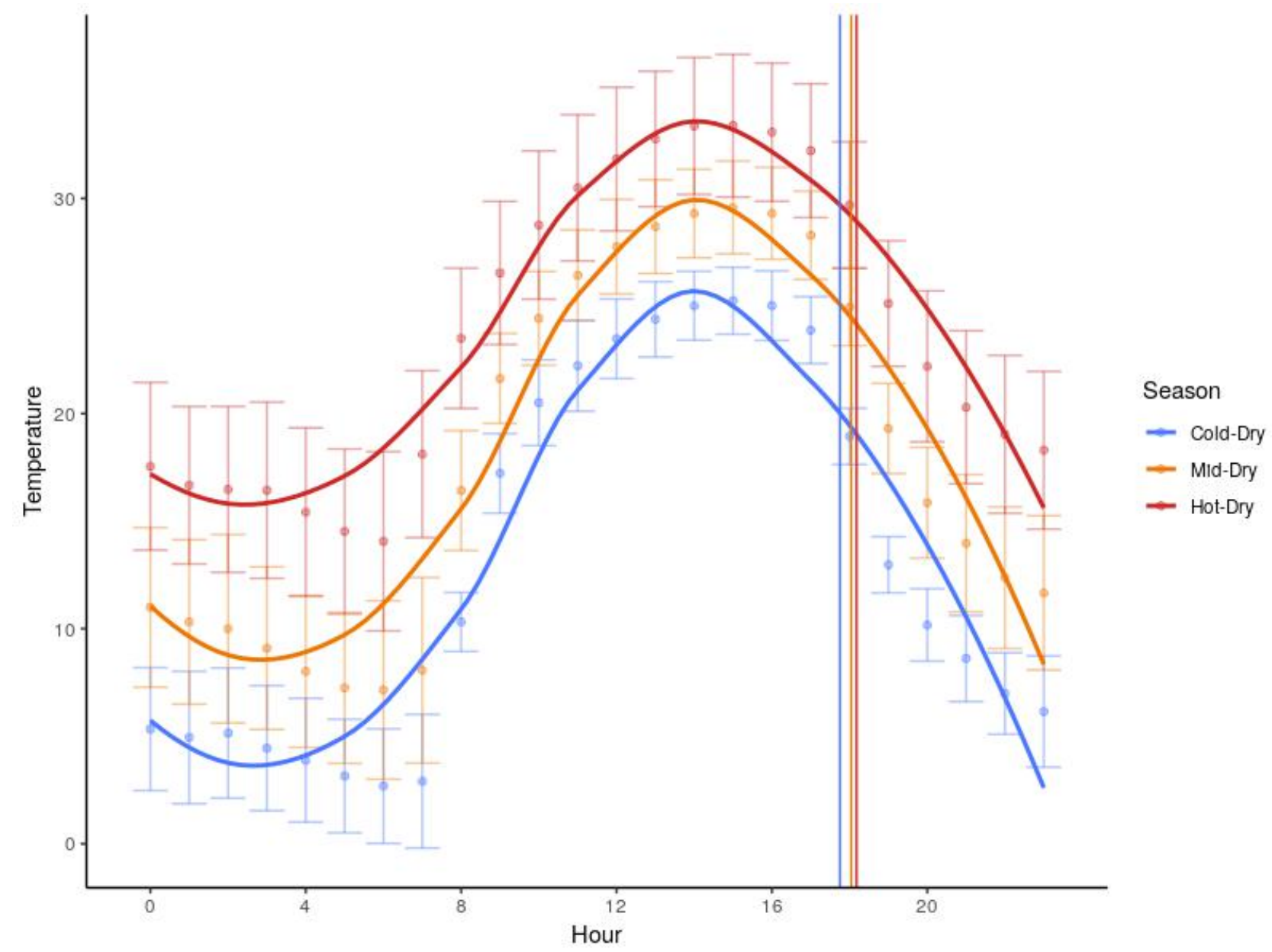


Supplementary Data SD3 Estimated coefficients of the model fitting the number of observed trips as a function of the average temperature experienced during the trip predicted from the hour of departure. All significant p-values are bold. Reference levels for factors are cold-dry season for the season and $24 \mathrm{~h}$ trips for trip types. SE: standard errors.

\begin{tabular}{|c|c|c|c|c|}
\hline Coefficients & Estimate & SE & $Z$ value & P-value \\
\hline Intercept & 12.4 & 1.9 & 6.6 & $<\mathbf{0 . 0 0 0 1}$ \\
\hline Average temperature experienced Tpredict & -0.9 & 0.2 & -5.9 & $<\mathbf{0 . 0 0 0 1}$ \\
\hline Hot-dry season & 3.0 & 2.7 & 1.1 & 0.28 \\
\hline Mid-dry season & 6.0 & 3.0 & 2.0 & $\mathbf{0 . 0 4}$ \\
\hline $48 h$ trip type & 19.5 & 6.3 & 3.1 & $\mathbf{0 . 0 0 2}$ \\
\hline$T \times$ Hot-dry season & 0.3 & 0.2 & 1.9 & 0.06 \\
\hline$T \times$ Mid-dry season & -0.03 & 0.2 & -0.2 & 0.87 \\
\hline$T \times 48 h$ trip type & -1.6 & 0.5 & -3.1 & $\mathbf{0 . 0 0 1}$ \\
\hline Mot-dry season $\times 48 h$ trip type & -15.0 & 8.9 & -1.7 & 0.09 \\
\hline Mid-dry season $\times 48 h$ trip type & 29.1 & 13.1 & 2.2 & $\mathbf{0 . 0 3}$ \\
\hline Hot-dry season $\times 48 h$ trip type & 1.4 & 0.6 & 2.4 & $\mathbf{0 . 0 2}$ \\
\hline Mid-dry season $\times 48 h$ trip type & -1.2 & 0.8 & -1.4 & 0.15 \\
\hline & & & & \\
\hline & & & & \\
\hline
\end{tabular}


Supplementary Data SD4 Multiple comparisons of the probability of realizing a 48 hours trip over a longer one according to the season. Estimates and p-values are extracted from a Tukey's multiple comparison tests (multcomp library in R, Hothorn et al. 2008)

\begin{tabular}{|c|c|c|c|c|}
\hline Comparison & Estimate & SE & $Z$ value & P-value \\
\hline Hot-dry vs. Cold-dry & 0.86 & 0.60 & 1.4 & 0.32 \\
\hline Mid-dry vs. Cold-dry & -0.45 & 0.51 & -0.88 & 0.65 \\
\hline Mid-dry vs. Hot-dry & -1.31 & 0.51 & -2.58 & 0.03 \\
\hline
\end{tabular}

